\title{
Stable Carbon Isotope Signature of Particulate Organic Matter in the Southwestern Sumatran Waters of the Eastern Indian Ocean
}

\author{
A'an J. Wahyudi ${ }^{1, *}$, Afdal $^{1}$, and Hanny Meirinawati ${ }^{1}$ \\ ${ }^{1}$ Research Center for Oceanography, Indonesian Institute of Sciences, Pasir Putih 1, Ancol Timur, Jakarta 14430, Indonesia \\ *Corresponding author: aanj001@lipi.go.id
}

\section{KEYWORDS}

Biogeochemistry

Chlorophyll-a

Nutrient

Organic matter origin

Particulate organic matter

\begin{abstract}
The Southwestern Sumatran Waters of the Eastern Indian Ocean are known to be affected by the South Java Current and the South Equatorial Counter Current. Many studies have been carried out in relation to upwelling and the Indonesian Through Flow. However, there has been no systematic study into the properties of the particulate organic matter in the Southwestern Sumatran Waters. Therefore, the organic matter in these waters in terms of its origin is unknown. As part of the Ekspedisi Widya Nusantara 2015 research cruise, this study aimed to examine the stable isotope $\delta^{13} \mathrm{C}$ signature of particulate organic matter (POM), especially with regards to the origins of the organic matter. The stable isotope $\delta^{13} \mathrm{C}$ is complemented by other variables such as chlorophyll-a, particulate organic carbon (POC), and nutrients (phosphate, silicate, ammonium and nitrate). The POC tends to be depth-dependent. The values of $\delta^{13} \mathrm{C}$ are $-23.56,-24.30$, and $-24.06 \%$ for 5,100 and $300 \mathrm{~m}$ depths, respectively. We found that POM tended to be isotopically lighter with increasing POC and chl-a, especially in the surface water, potentially due to the preferential lighter carbon isotope for metabolism by the primary producer. The origin of POM in the Southwestern Sumatran waters is marine end-member in the surface (up to $100 \mathrm{~m}$ depth) and mixed compositions at the surface of twilight zone (100-300 m depth). The next layer, i.e. twilight zone (more than $300 \mathrm{~m}$ depth), is terrigenous end-member. The surface POM of SSW, as shown in $5 \mathrm{~m}$ depth, is not freshly produced and tends to be either autochthonous or allochthonous.
\end{abstract}

(c) The Author(s) 2019. This article is distributed under a Creative Commons Attribution-ShareAlike 4.0 International license.

\section{INTRODUCTION}

The Southwestern Sumatran Waters (SSW) are located in the eastern Indian Ocean (EIO). This area is affected by both the South Java Current (SJC) and the South Equatorial Counter Current (SECC) (Schott et al. 2009; Hood et al. 2011). According to the global current pattern, these two main currents in the EIO, are affected by the monsoon (Susanto et al. 2001; Hood et al. 2011). Furthermore, the Southwestern Sumatran waters have been known as an area which is affected annually by upwelling. The upwelling in the EIO occurs along the island chain from Sumatra, Java, Bali, Lombok, Flores to Alor, during the southeast monsoon period (Susanto et al. 2001). The cool temperature signal of the upwelling firstly occurs east of the island of Lombok (April-May). Then, it proceeds westward along the southern Java waters, up to the Sunda Strait (late June), and then flows northwest into the western Sumatra waters (early $\mathrm{Au}-$ gust). Then, the retreat of the upwelling is very rapid and simultaneous across the whole island chain in October $\left(\mathrm{Su}^{-}\right.$ santo et al. 2001; Yu et al. 2016).

Many studies about the chemical profile and characteristic of the particulate matter, solid organic ligand, and others, have been done (e.g. Hirose and Tanoue 1998; Boyd et al. 1999; Hirose et al. 2011). For instance, Boyd et al. (1999) suggested that the upper water column is characterized by two days turnover of particulate organic carbon (POC) and a low but constant downward flux of POC. Studies by Hirose and Tanoue (1998) and Hirose et al. (2011) suggest that the increasing of the POC level with depth is followed by the decreasing of the concentrations of the strong organic ligand in particulate matter. Profile of those chemical constituents shows unique vertical distribution along the water column, where the maximum concentration is at the surface and gradually decreases with depth. The vertical profile of particulate organic matter (POM) (between 100-1000 $\mathrm{m}$ depth) shows a biogeochemical process, especially the sinking of materials produced by plankton in the euphotic layer (Hirose et al. 2011). This means that the vertical profile of POM is also closely related to the export vertical flux of the particles (Hirose and Tanoue 1998).

There has been limited studies about POM spatial distribution and its isotopic profile, especially in maritime continent areas (the Indonesian archipelago). Isotopic profile of POM is one of the important parameters to determine the origin of POM materials. Materials origin of POM itself is important for understanding the dynamics of biological pump such as POM's aggregation-disaggregation and fragmentation (Cavan et al. 2017). POM production may not be uniform since it is site and depth-dependent (Sarma et al. 2014), that condition imply the POM composition should be understood thoroughly. Other studies of POM and its isotopic profile have been conducted in the southwestern Atlantic (Lara et al. 2010), South China Sea (e.g. Liu et al. 2007a; 
Kaiser et al. 2014), or the Danshuei estuary of the northern Taiwan (Liu et al. 2007b). Both POM and nutrients are important components in the biogeochemical process such as the biological pump (Liu et al. 2007b; Lara et al. 2010; Hirose et al. 2011), especially in the zone which is affected by both the SJC and the SECC currents, such as the SSW.

In a region with the dual current affection, the SSW have high opportunities in organic matter mixing due to the dual current itself or the upwelling event. Considering this physical characteristic, it means that the POM origin in this area is important and should be further investigated. One of the approach is using stable isotope signature.

Stable isotope signatures, especially carbon and nitrogen, are widely used for identifying the properties of water mass including the organic matter inside (e.g. Otero et al. 2000; Hwang et al. 2013; Kaiser et al. 2014), or the organic matter origin (e.g. Liu et al. 2007a; Lara et al. 2010). Besides the organic matter origin, stable isotope signatures can be used alongside the nutrient properties of the seawater (i.e. nitrate, phosphate, ammonium) to elucidate the variations of $\delta^{13} \mathrm{C}$ properties (Lara et al. 2010). This kind of data is useful for analyzing both the material and the nutrient mixing during physical processes in the region, such as the upwelling.

This study aims to evaluate the stable isotope $\delta^{13} \mathrm{C}$ signature of POM, especially in terms of understanding the organic matter origin. We also investigate the factors that contribute to $\delta^{13} \mathrm{C}$ variability such as chl-a (as the phytoplankton biomass indicator) and nutrients.

\section{MATERIALS AND METHODS}

\subsection{Field sampling}

Conductivity, temperature and depth (CTD) instruments were deployed at 26 sites covering areas in the Sunda Strait, the Enggano Waters and the SSW (Figure 1). However due to the technical reasons, the water sampling was conducted only at 21 sites as shown in Table 1 . The sampling was conducted during Ekspedisi Widya Nusantara (E-WIN) 2015 research cruise starting from Jakarta to Padang on 718 May 2015 (see Wahyudi et al. (2015) for details informa-

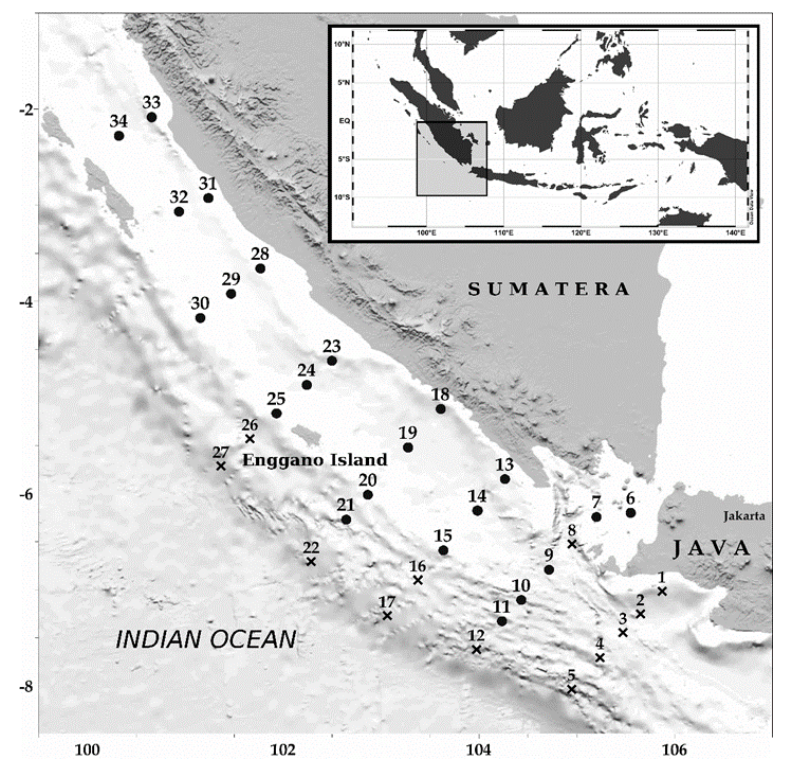

FIGURE 1. Study site in Eastern Indian Ocean. Filled circle $(\bullet)$ is the site where the CTD was deployed. The $X$ is the planned site that due to the bad weather, the vessel could not reach those sites. tion about E-WIN 2015). Water samples were taken using a rosette sampler that was deployed together with the CTD instruments. Water samples were taken at 5, 100, 200, 300, and $1000 \mathrm{~m}$ depth (2n per depth). The study site covered 200 to $4500 \mathrm{~m}$ of water depth.

\subsection{Stable isotope analysis of POM}

Sea water $(1.0 \mathrm{~L})$ was filtered into the Whatman GF/F glass fiber filter (D $25 \mathrm{~mm}$ ). The filtrate was acidified to remove inorganic carbon using $\mathrm{HCl}$ fume for $1 \mathrm{~min}$ and neutralized by placing it in a vacuum desiccator with concentrated $\mathrm{NaOH}$ for $24 \mathrm{~h}$. The dry weight was measured after oven drying at $60^{\circ} \mathrm{C}$ up to constant weight.

Each filtrate sample (in glass fiber filter GF/F) was then packed into a tin capsule (Lüdiswiss Sn 98, d 9/10 mm). Further analysis was conducted using an Isotope Ratio Mass Spectrometer (IRMS) i.e. Thermo Delta Plus XP coupled to a trace GC ultra with a combi PAL autosampler. The analysis was conducted at Iso-trace Research, University of Otago (New Zealand).

The stable isotope ratios of ${ }^{13} \mathrm{C} /{ }^{12} \mathrm{C}$ are expressed as $\delta^{13} \mathrm{C}$. The isotopic ratios were normalized using Pee Dee Belemnite (PDB). Isotope ratio (R) calculation, given as permillion (\%o) deviation from the standard value $\left(\delta^{13} \mathrm{C}\right)$, where (Equation 1):

$$
R={ }^{13} \mathrm{C} /{ }^{12} \mathrm{C}
$$

and (Equation 2):

$$
\delta^{13} C(\%)=\left(\left(R_{\text {sample }} / R_{\text {standard }}\right)-1\right) \times 1000
$$

TABLE 1. Rosette sampler deployment for water sampling altogether with CTD.

\begin{tabular}{llll}
\hline Site & \multicolumn{1}{c}{ Chl- $a$} & \multicolumn{1}{c}{ Nutrient } & \multicolumn{1}{c}{ POM } \\
\hline St6 & $5,50,100,200 \mathrm{~m}$ & NA & $5,100,300 \mathrm{~m}$ \\
St7 & $5,50,100,200 \mathrm{~m}$ & $5,25,100 \mathrm{~m}$ & $5,100,300 \mathrm{~m}$ \\
St9 & $5,50,100,200 \mathrm{~m}$ & $5,25,100 \mathrm{~m}$ & $5,100,300 \mathrm{~m}$ \\
St10 & $5,50,100,200 \mathrm{~m}$ & $5,25,100 \mathrm{~m}$ & $5,100,300 \mathrm{~m}$ \\
St11 & $5,50,100,200 \mathrm{~m}$ & NA & $5,100,300 \mathrm{~m}$ \\
St13 & $5,50,100,200 \mathrm{~m}$ & $5,25,100 \mathrm{~m}$ & $5,100,300 \mathrm{~m}$ \\
St14 & $5,50,100,200 \mathrm{~m}$ & NA & $5,100,300 \mathrm{~m}$ \\
St15 & $5,50,100,200 \mathrm{~m}$ & $5,25,100 \mathrm{~m}$ & $5,100,300 \mathrm{~m}$ \\
St18 & $5,50,100,200 \mathrm{~m}$ & $5,25,100 \mathrm{~m}$ & $5,100,300 \mathrm{~m}$ \\
St19 & $5,50,100,200 \mathrm{~m}$ & NA & $5,100,300 \mathrm{~m}$ \\
St20 & $5,50,100,200 \mathrm{~m}$ & $5,25,100 \mathrm{~m}$ & $5,100,300 \mathrm{~m}$ \\
St23 & $5,50,100,200 \mathrm{~m}$ & $5,25,100 \mathrm{~m}$ & $5,100,300 \mathrm{~m}$ \\
St24 & NA & $5,25,100 \mathrm{~m}$ & NA \\
St25 & $5,50,100,200 \mathrm{~m}$ & NA & NA \\
St28 & $5,50,100,200 \mathrm{~m}$ & NA & $5,100,300 \mathrm{~m}$ \\
St29 & $5,50,100,200 \mathrm{~m}$ & NA & $5,100,300 \mathrm{~m}$ \\
St30 & $5,50,100,200 \mathrm{~m}$ & NA & $5,100,300 \mathrm{~m}$ \\
St31 & $5,50,100,200 \mathrm{~m}$ & $5,25,100 \mathrm{~m}$ & NA \\
St32 & $5,50,100,200 \mathrm{~m}$ & $5,25,100 \mathrm{~m}$ & NA \\
St33 & $5,50,100,200 \mathrm{~m}$ & NA & NA \\
St34 & $5,50,100,200 \mathrm{~m}$ & NA & NA \\
\hline
\end{tabular}

Note: Rows 2-4 represent the kinds of samples that were obtained during the cruise. Chl- $a$ is for chlorophyll- $a$, nutrient is for macro-nutrient (phosphate, nitrate, ammonium and silicate), POM is for particulate organic matter. 
The isotopic and elemental values were determined using laboratory reference materials (USGS-40 and USGS-41). Control materials were used to determine precision and accuracy, namely EDTA-OAS and IAEA-414:Algae. Detailed information for stable isotope analysis and the usage of those references can be found in, e.g., Post (2002), Jacob et al. (2005), Lara et al. (2010), Carter et al. (2011), and Wahyudi et al. (2013).

\subsection{Analysis of nutrient and chlorophyll- $a$}

Water samples were taken representing three depths (i.e. 5, 100 and $300 \mathrm{~m}$, respectively). About $500 \mathrm{~mL}$ seawater was extracted from the rosette sampler to a polyethylene bottle. The water sample was filtrated using nitrocellulose 0.45 $\mu \mathrm{m}$. The nutrient was analyzed using spectrophotometric methods (Shimadzu UV-1201V) with wavelengths 885 , 543, 630 and $810 \mathrm{~nm}$ for phosphate, nitrate, ammonium, and silicate measurement, respectively. Phosphate was analyzed according to the formation of the molybdate blue complex, according to the methods used by Murphy and Riley (1962), which were later modified by Strickland and Parsons (1972). Nitrate was analyzed as nitrite using reduction in the cadmium-cuprum column and reacted using sulfanilamide according to the methods used by Parsons et al. (1984). Meanwhile, for nitrite concentration measurement, the methods were similar to nitrate measurement without the reduction processes. Both ammonium and silicate were measured using the standard methods employed by Strickland and Parsons (1972). Meanwhile, the measurement of chlorophyll- $a$ was conducted using fluorometric methods according to Cochlan and Hendorn (2012).
Analysis for nutrient and chlorophyll- $a$ was analyzed from all sampling depth, except $1000 \mathrm{~m}$. Further, since the IRMS could not detect the $\delta^{13} \mathrm{C}$ of this depth (probably due to the amount of water samples), the later analysis to determine the POM profile in $1000 \mathrm{~m}$ depth used secondary data instead.

\subsection{Statistics}

Normal distribution was a priori checked using the ShapiroWilk normality test. Data were then compared using Analysis of Variance (ANOVA) complement with Tukey contrast were performed ( $\alpha=0.05$; CI 95\%), while non-normal distribution data were analyzed using the Kruskal-Wallis rank sum test $(\alpha=0.05)$. All statistical analysis was performed using $\mathrm{R}$ version 3.4.2.

\section{RESULTS}

The water temperature and salinity of sampling sites has typical tropical water characteristics. The lowest surface water temperature was recorded in the Sunda Strait $\left(29.5^{\circ} \mathrm{C}\right)$, while the highest temperature is near the equator $\left(30.3^{\circ} \mathrm{C}\right)$. Seawater salinity ranges from 32.8 to $33.8 \mathrm{psu}$. The chl- $a$ value of the surface water ( $5 \mathrm{~m}$ depth) is relatively lower than the chl- $a$ value of the $100 \mathrm{~m}$ depth water-mass. However, the Kruskall-Wallis rank sum test verifies that there is no significant difference among chl- $a$ collected from different depths $\left(\chi^{2}=1.03, \mathrm{df}=1, p\right.$-value $\left.=0.31\right)$.

Particulate organic carbon (POC) concentrations shows a significant difference over different water depth (Kruskal-Wallis rank sum test chi-squared $=16.1283$, df $=$
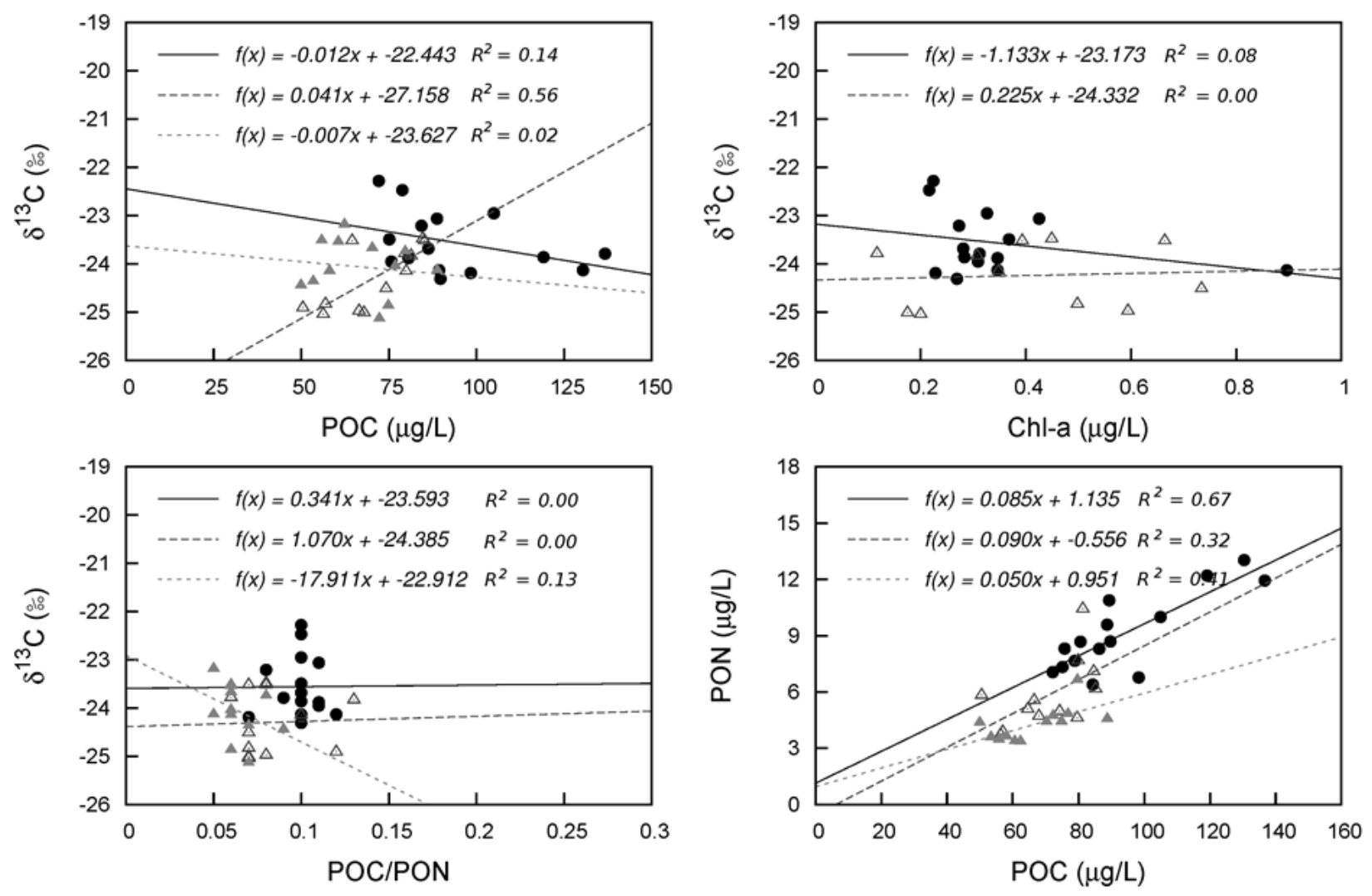

$5 \mathrm{~m}$

FIGURE 2. Profile $\delta^{13} \mathrm{C}$ in correlation with: Particulate Organic Carbon (POC), chlorophyll-a and POC/Particulate Organic Nitrate (PON) quotient; POC against PON of all data from three depth (5, 100 and $300 \mathrm{~m}$, respectively). 
$2, p$-value $=0.0003146)$. The mean value of POC at 5, 100 and $300 \mathrm{~m}$ depths are $88.73 \pm 20.20,71.09 \pm 11.91$, and 66.32 $\pm 11.96 \mu \mathrm{g} / \mathrm{L}$, respectively. These values are the same as $7835.7 \pm 1683.1,5887.0 \pm 992.8$, and $5576.5 \pm 996.5 \mu \mathrm{mol} / \mathrm{m}^{3}$, respectively. A similar result is shown by particulate organic nitrogen (PON), in that the values at 5, 100 and 300 $\mathrm{m}$ depths are significantly different (Kruskall Wallis rank sum test chi-squared $=25.35, \mathrm{df}=2, p$-value $=3.12 \times 10^{6}$ ). The mean value of PON at 5, 100 and $300 \mathrm{~m}$ depths are 8.68 $\pm 2.09,5.32 \pm 1.88$, and $4.39 \pm 0.93 \mu \mathrm{g} / \mathrm{L}$, respectively. The concentration values at 5,100 and $300 \mathrm{~m}$ depths are $651.6 \pm$ $149.2,415.1 \pm 134.0$, and $306.1 \pm 66.3 \mu \mathrm{mol} / \mathrm{m}^{3}$, respectively.

A molar ratio value of carbon and nitrogen $(\mathrm{C}: \mathrm{N}$ mol ratio) of POM samples shows significant difference among the different depths $(p$-value $<0.01)$. Post hoc tests using Tukey contrasts (CI 95\%) show that the C:N mol ratio of POM from depth $5 \mathrm{~m}<100 \mathrm{~m}<300 \mathrm{~m}$ (Table 2, Figure 2). The mean values are 12.19, 14.95 and 18.50, respectively. However, there is almost no significant linear correlation among POM variables as shown in Figure 2.

The nutrient profile varies among different depth and location. Both silicate and nitrate concentrations along the stations at $100 \mathrm{~m}$ depth are higher than at $5 \mathrm{~m}$ depth (Figure 3). The average value of silicate concentration at 5 and $100 \mathrm{~m}$ depth are 0.14 and $0.57 \mathrm{mg} / \mathrm{L}$, respectively. The Wilcoxon signed rank test justify that both nitrate and silicate from 5 and $100 \mathrm{~m}$ depths are significantly different $\left(p\right.$-value $=0.0001426$ and 0.0001424 , for $\mathrm{NO}_{3}$ and $\mathrm{SiO}_{3}$, respectively). The average nitrate concentrations are 0.07 and $0.32 \mathrm{mg} / \mathrm{L}$ for 5 and $100 \mathrm{~m}$ depth, respectively. Phosphate concentrations of surface water $(5 \mathrm{~m})$ along the stations are lower (average $0.01 \mathrm{mg} / \mathrm{L}$ ) than the concentration at $100 \mathrm{~m}$ depths (average $0.04 \mathrm{mg} / \mathrm{L}$ ). The average concentration of $\mathrm{PO}_{4}$ from 5 and $10 \mathrm{~m}$ depths are significantly
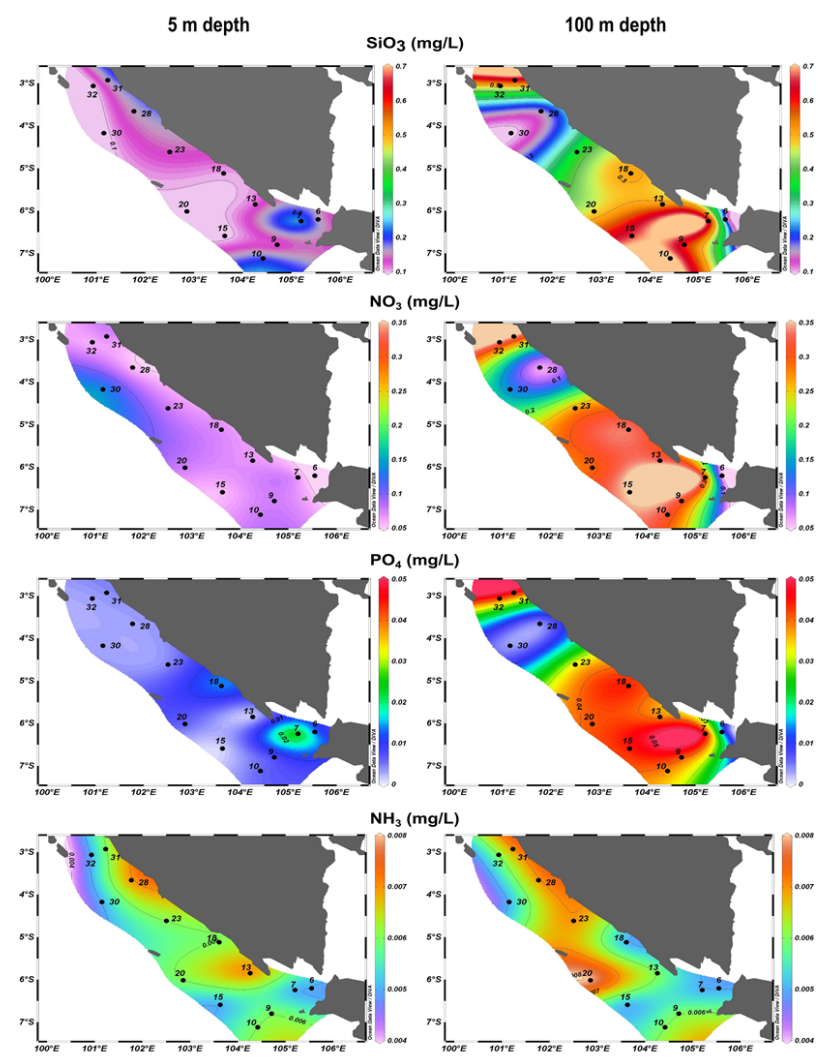

FIGURE 3. Spatial variability of silicate, nitrate, phosphate and ammonium from $5 \mathrm{~m}$ depth (left panel) and $100 \mathrm{~m}$ depth (right panel), respectively. The spatial distribution was generated using Ocean Data View. different (Wilcoxon signed rank test $p$-value $=0.0001417$ ). A different trend is shown by the ammonium concentration, which is relatively similar between the 5 and $100 \mathrm{~m}$ depths (Figure 3). However, the statistical analysis suggested that the ammonium concentration from the different depths are significantly different (Wilcoxon signed rank test $p$-value $=$ 0.0001345).

The value of $\delta^{13} \mathrm{C}$ in the present study has a correlation with the POC, chl- $a$ concentration and the water depth. The value of $\delta^{13} \mathrm{C}$ tends to be varied and significantly different among the POM collected at different depths (One Way ANOVA $p$-value $=0.0117)$. The mean values of $\delta^{13} \mathrm{C}$ are $-23.56 \pm 0.63,-24.29 \pm 0.65$ and $-24.06 \pm 0.58 \%$ o for 5,100 and $300 \mathrm{~m}$ depths, respectively. The POM tended to be isotopically lighter with increasing POC and chl- $a$, especially in the surface water at $5 \mathrm{~m}$ depths (Figures 2 and 4). However, the opposite trend is shown by the water from 100 $\mathrm{m}$ depths, the POM's $\delta^{13} \mathrm{C}$ tended to be heavier follow the increase of POC. Furthermore, the value of POM's $\delta^{13} \mathrm{C}$ in water surface tended to be heavier than the 100 and 300 $\mathrm{m}$ depths (Figure 4). The value of $\delta^{13} \mathrm{C}$ at $300 \mathrm{~m}$ depths tended to decrease with the increasing of the POC/PON ratio (Figure 2). According to Figure 5, all POM collected at $5 \mathrm{~m}$ depths has a $\mathrm{C} / \mathrm{N}$ ratio below 17 , which is significantly

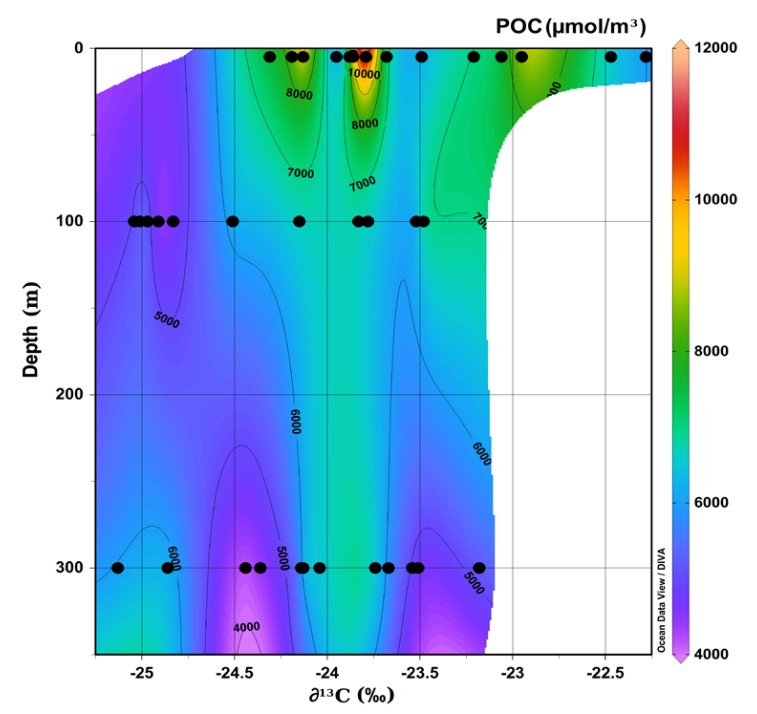

FIGURE 4. Isotopic profile of POM that shows depth- and POC-dependent.

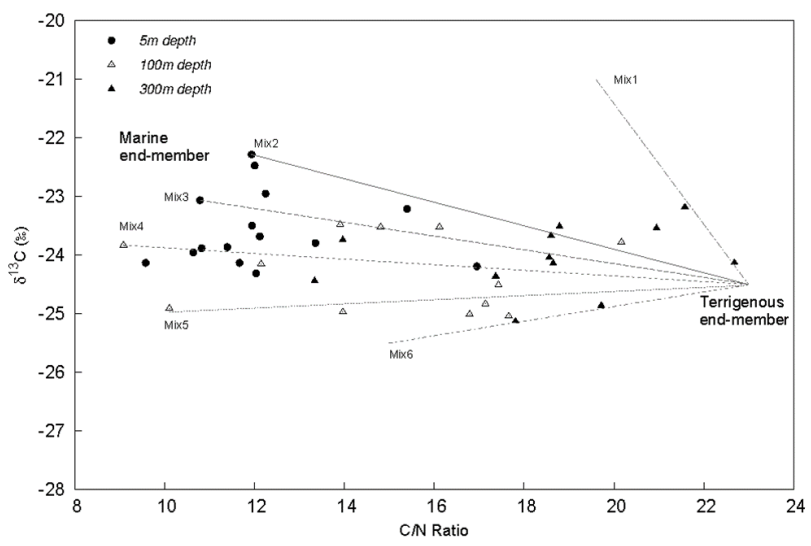

FIGURE 5. Scatter plot of the $\delta^{13} \mathrm{C}$ value of POM vs. $\mathrm{C} / \mathrm{N}$ ratio at three depths. The modeled lines represent hypothetical mixing between terrigenous end-member $\left(\delta^{13} \mathrm{C}=-24.2 \%\right.$ and $\mathrm{C} / \mathrm{N}$ ratio $\left.=23\right)$ and marine end-members of different compositions. $\mathrm{C} / \mathrm{N}$ ratio more than 20 is categorized as terrigenous end-member (Gilhooly et al. 2008). 
TABLE 2. Statistical analysis of POM properties data.

\begin{tabular}{|c|c|c|c|c|c|c|c|c|c|}
\hline \multirow[t]{3}{*}{ Variable } & \multicolumn{3}{|c|}{ Normality test $(a=0.05)$} & \multicolumn{6}{|c|}{ Differentiation test according to the depth $(a=0.05)$} \\
\hline & \multirow[t]{2}{*}{ Test } & \multicolumn{2}{|r|}{ Result } & \multirow[t]{2}{*}{ Test } & \multicolumn{2}{|c|}{ Result } & \multirow{2}{*}{$\begin{array}{l}\text { Post-hoc } \\
\text { test }\end{array}$} & \multicolumn{2}{|r|}{ Result } \\
\hline & & $p$-value & Interpretation & & $p$-value & Interpretation & & $\mathrm{Cl}$ & Interpretation \\
\hline $\mathrm{C} / \mathrm{N}$-ratio & $\begin{array}{l}\text { Shapiro-Wilk } \\
\text { normality } \\
\text { test }\end{array}$ & 0.084 & $\begin{array}{l}\text { Normal } \\
\text { distribution }\end{array}$ & $\begin{array}{l}100 \mathrm{~m} 300 \mathrm{~m} \\
5 \mathrm{~m}\end{array}$ & $2.22 \mathrm{E}-006$ & $\begin{array}{l}\text { Significant } \\
\text { difference in } \\
\text { depth }\end{array}$ & $\begin{array}{l}\text { Tukey } \\
\text { contrasts }\end{array}$ & $95 \%$ & $\begin{array}{l}\text { All depth has } \\
\text { different C:N } \\
\text { mol ratio; } 5 \mathrm{~m}< \\
100 \mathrm{~m}<300 \mathrm{~m}\end{array}$ \\
\hline PON & $\begin{array}{l}\text { Shapiro-Wilk } \\
\text { normality } \\
\text { test }\end{array}$ & 0.007 & $\begin{array}{l}\text { Not normal } \\
\text { distribution }\end{array}$ & $a$ " “ab" “b & $3.12 \mathrm{E}-006$ & $\begin{array}{l}\text { Significant } \\
\text { difference in } \\
\text { depth; } 5 \mathrm{~m}> \\
100 \mathrm{~m}>300 \mathrm{~m}\end{array}$ & & & \\
\hline POC & $\begin{array}{l}\text { Shapiro-Wilk } \\
\text { normality } \\
\text { test }\end{array}$ & 0.004 & $\begin{array}{l}\text { Not normal } \\
\text { distribution }\end{array}$ & $\begin{array}{l}\text { Kruskal-Wallis } \\
\text { rank sum test }\end{array}$ & $3.15 \mathrm{E}-004$ & $\begin{array}{l}\text { Significant } \\
\text { difference in } \\
\text { depth; } 5 \mathrm{~m}> \\
100 \mathrm{~m}>300 \mathrm{~m}\end{array}$ & & & \\
\hline Chl-a & $\begin{array}{l}\text { Shapiro-Wilk } \\
\text { normality } \\
\text { test }\end{array}$ & 0.004 & $\begin{array}{l}\text { Not normal } \\
\text { distribution }\end{array}$ & $\begin{array}{l}\text { Kruskal-Wallis } \\
\text { rank sum test }\end{array}$ & 0.3114 & $\begin{array}{l}\text { Insignificant } \\
\text { difference; } \\
5 \mathrm{~m}=100 \mathrm{~m}\end{array}$ & & & \\
\hline$\delta^{13} \mathrm{C}$ & $\begin{array}{l}\text { Shapiro-Wilk } \\
\text { normality } \\
\text { test }\end{array}$ & 0.393 & $\begin{array}{l}\text { Normal } \\
\text { distribution }\end{array}$ & $\begin{array}{l}\text { One-way } \\
\text { ANOVA }\end{array}$ & 0.0117 & $\begin{array}{l}\text { Significant } \\
\text { difference in } \\
\text { depth }\end{array}$ & $\begin{array}{l}\text { Tukey } \\
\text { contrasts }\end{array}$ & $95 \%$ & $\begin{array}{l}100 \text { m } 300 \text { m } 5 \text { m } \\
\text { "a" “ab" "b" }\end{array}$ \\
\hline
\end{tabular}

different compared to POM collected from the 100 and 300 m depths (One Way ANOVA $p$-value $<0.01$; Tukey contrasts CI 95\%).

\section{DISCUSSION}

\subsection{Organic matter origin}

Using the comparison between the $\mathrm{C} / \mathrm{N}$ ratio versus $\delta^{13} \mathrm{C}$ (Figure 5), we can predict the origin of the POM in the Southwestern Sumatran waters. Liu et al. (2007a) suggested that the POM is a mixture of marine and terrigenous origin organic matter. In this study we used representative values from all data collected, i.e. the lowest $\mathrm{C} / \mathrm{N}$ ratio, the highest $\delta^{13} \mathrm{C}$ value and others, to determine parameters for the terrigenous- and marine end-member origins (Figure 5). The terrigenous end-member is determined in this model (Figure 5) to have a $\mathrm{C} / \mathrm{N}$ ratio of 23 and $\delta^{13} \mathrm{C}$ value of $-24.2 \%$ o (different from Liu et al. (2007b) that used a $\mathrm{C} / \mathrm{N}$ ratio of 22 and $\delta^{13} \mathrm{C}$ value of $-25.5 \%$ o). Typical $\mathrm{C} / \mathrm{N}$ values for marine-end member is $<6.6$ (Martiny et al. 2014) and terrestrially-derived organic matters is $>20$ (Gilhooly et al. 2008). However, the marine end-member (both the $\mathrm{C} / \mathrm{N}$ ratio and $\delta^{13} \mathrm{C}$ ) had various values, with mean values of 10.48 and $-23.52 \%$ or the $\mathrm{C} / \mathrm{N}$ ratio and the $\delta^{13} \mathrm{C}$, respectively. Kaiser et al. (2014) suggested that $\delta^{13} \mathrm{C}$ values ranging from -24 to $-17 \%$ ore identical with the marine phytoplankton isotopic signatures.

The results suggest that POM collected at $300 \mathrm{~m}$ depth are composed of the terrigenous end-member materials, meanwhile POM collected at the $5 \mathrm{~m}$ depth are mainly composed of the marine end-member materials. However, POM collected in the $100 \mathrm{~m}$ depth were varied, i.e. some data shows that the POM is likely to be composed of marine end-member and the others are terrigenous end-member. This result suggests a similar trend found by a study of POM in the South China Sea, which suggested that POM collected from more than $400 \mathrm{~m}$ to $1200 \mathrm{~m}$ tended to be composed by terrigen (Liu et al. 2007a). Therefore, the gradation of POM major compositions from surface to the deep layer can be suggested as follows: 1) marine end-member in the surface layer (up to $100 \mathrm{~m}$ depth), which is possibly due to the high biomass of phytoplankton in the euphotic layer as shown by the chl- $a$ concentrations, 2) mixed compositions at the upper part of the twilight zone (100 to 300 $\mathrm{m}$ depth), show that some of the terrigenous end-member may be composed of the freshly produced POM (Figure 6), 3) terrigenous end-member in the twilight zone (300 to $1000 \mathrm{~m}$ depth), 4) marine end-member in the deep layer (more than $1000 \mathrm{~m}$; following Liu et al. (2007b)). However, this suggestion should be considered as the usual POM layers in the region when the upwelling is not occurring (AprilMay). Thus, when the upwelling occurs in the region (i.e. early August according to Susanto et al. (2001)), the profile could be different.

The twilight zone (100-1000 m depth) is considered to be the zone highly influenced by the biological pump, especially by the sinking of biogenic material, which is produced by plankton in the euphotic layer (Hirose et al. 2011). The variation of POM composition in the twilight zone can be driven by both the carbon biological pump (CBP) and microbial loop mechanisms. For instance, microbial organisms (bacteria, archaea, and viruses) can remineralize the POM, which respires back the carbon into carbon dioxide (Wassmann 1997; Sanders et al. 2014). This process occurs in the layer with minimal or no light (Arístegui et al. 2002), as in the twilight zone down to the deep layer.

These facts suggest that the marine end-member materials can be the major component of POM in the surface waters because these waters contain the euphotic zone with more marine planktonic organisms. The terrigenous mixed with marine end-member constitutes the POM in the twilight zone (up to $1000 \mathrm{~m}$ ). Within this zone, the POM which is pumped to the deep from the surface layer may be degraded by microbes (Sanders et al. 2014). This process accompanied by the mixing of the terrigenous input makes the POM composition change. Also, within this zone, the production of fresh POM may occur (see the below section). Marine snow together with phytodetritus, fecal pellets and transparent exopolymer particles (TEP) may also be formed within the twilight zone (Turner 2015), further adding to the variables that determine the POM properties. 

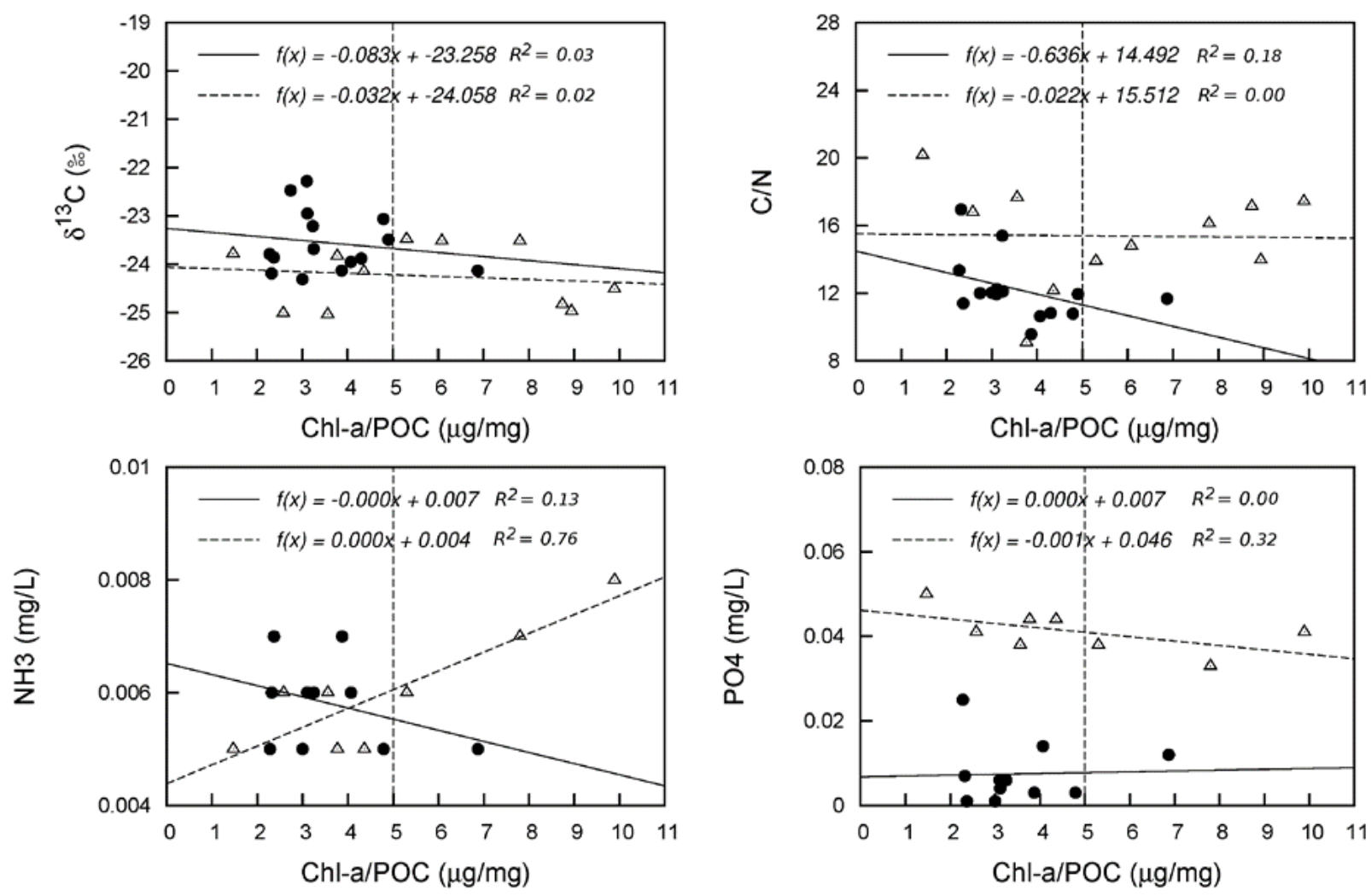

FIGURE 6. Properties of water samples and POM collected during E-WIN 2015 vs. the chl-a/POC ratio. Following Cifuentes et al. (1988) and Liu et al. (2007b) that samples with the chl-a/POC ratio above $5 \mu \mathrm{g} . \mathrm{mg}^{-1}$ are considered as containing high fraction of freshly produced POM. Filled circle and open triangular are samples from $5 \mathrm{~m}$ and $100 \mathrm{~m}$ depth, respectively.

\subsection{Depth-dependent profile of POM's carbon isotope}

The value of $\delta^{13} \mathrm{C}$ tended to be various and significantly different among the POM collected at different depths. POM in the surface water tended to be isotopically lighter following the increase of POC and chl- $a$. POM's $\delta^{13} \mathrm{C}$ tended to be heavier following the increase of $\mathrm{POC}$ in the water from depths of $100 \mathrm{~m}$. However, the correlation is not considered significant enough (Figure 2). The surface layer was dominated by living planktonic organisms, that fractionation of ${ }^{13} \mathrm{C}$ is still at a minimum since they are primary producer (Post 2002).

Overall, the carbon stable isotope is heavier in the surface layer compared to the 100 or $300 \mathrm{~m}$ depth (Figure 5). The depth-dependent POM's carbon isotope may caused by the preferential fractionation of the carbon isotope as suggested by Liu et al. (2007b). Surface layer POM mainly composed by the phytoplankton (i.e. primary producer) that prefer using the lighter carbon isotope for its metabolism. Thus more heavier carbon then will be fractionated. Meanwhile, on the 100 or $300 \mathrm{~m}$ depth layer, living plankton may be decrease that cause same opportunity for lighter and heavier carbon isotope to be remineralized. The another possible factors could be the preferential remineralization of nitrogen rather than carbon. Letscher et al. (2015) suggested that in the case of dissolved organic matter, the order of the remineralization lifetimes of carbon is longer than nitrogen $(\mathrm{C}>\mathrm{N})$.

\subsection{Autochthonous versus freshly produced POM}

Autochthonous POM is determined as the POM that formed from the indigenous sources. The opposite is allochthonous, i.e. formed from the non-indigenous sources. All freshly produced POM should be autochthonous, how- ever, not all autochthonous POM may be freshly produced (Liu et al. 2007b).

Freshly produced POM is one that is composed of the newly produced ${ }^{13} \mathrm{C}$-enriched POC (Liu et al. 2007b). That is, the bulk of POM is newly aggregated. Following $\mathrm{Ci}^{-}$ fuentes et al. (1988) and Liu et al. (2007b) samples with a chla/POC ratio above $5 \mu \mathrm{g} \cdot \mathrm{mg}_{-1}$ were considered as containing a high fraction of freshly produced/aggregated POM.

Half of the POM collected from $100 \mathrm{~m}$ depths were considered as freshly produced POM (Figure 6). The samples from $5 \mathrm{~m}$ depths, however, showed a different tendency. This trend is different with the typical oceanic profile. In the twilight zone, some of the terrigenous end-member may be composed of freshly produced POM (Figure 6).

Although the POM in the surface water mass $(5 \mathrm{~m})$ was not considered as freshly produced POM (Figure 6), its main components are marine end-members, which means the POM is autochthonous. POM at the 100 and $300 \mathrm{~m}$ depths have a different profile. Only half of the $100 \mathrm{~m}$ depth POM are freshly produced, and almost all the POM at 300 $\mathrm{m}$ depths are freshly produced. According to Liu et al. (2007b), the freshly produced POM at $300 \mathrm{~m}$ depths can therefore be categorized as autochthonous although consist of mainly terrigenous end-member (Figure 5). Therefore, we can suggest that autochthonous POM may consist of marine or terrigenous end-member. We also suggest that the freshly produced POM may be composed of marine or terrigenous end-member.

\subsection{Contribution of chl- $a$ and nutrient on isotopic profile}

Linear regression between the nutrients parameters and the $\delta^{13} \mathrm{C}$ shows various trends (Figure 7). Nitrate and $\delta^{13} \mathrm{C}$ have a significant relationship at $\alpha=0.1$, especially within samples collected from $5 \mathrm{~m}$ depth $\left(p\right.$-value $=0.086, \mathrm{R}^{2}=$ 

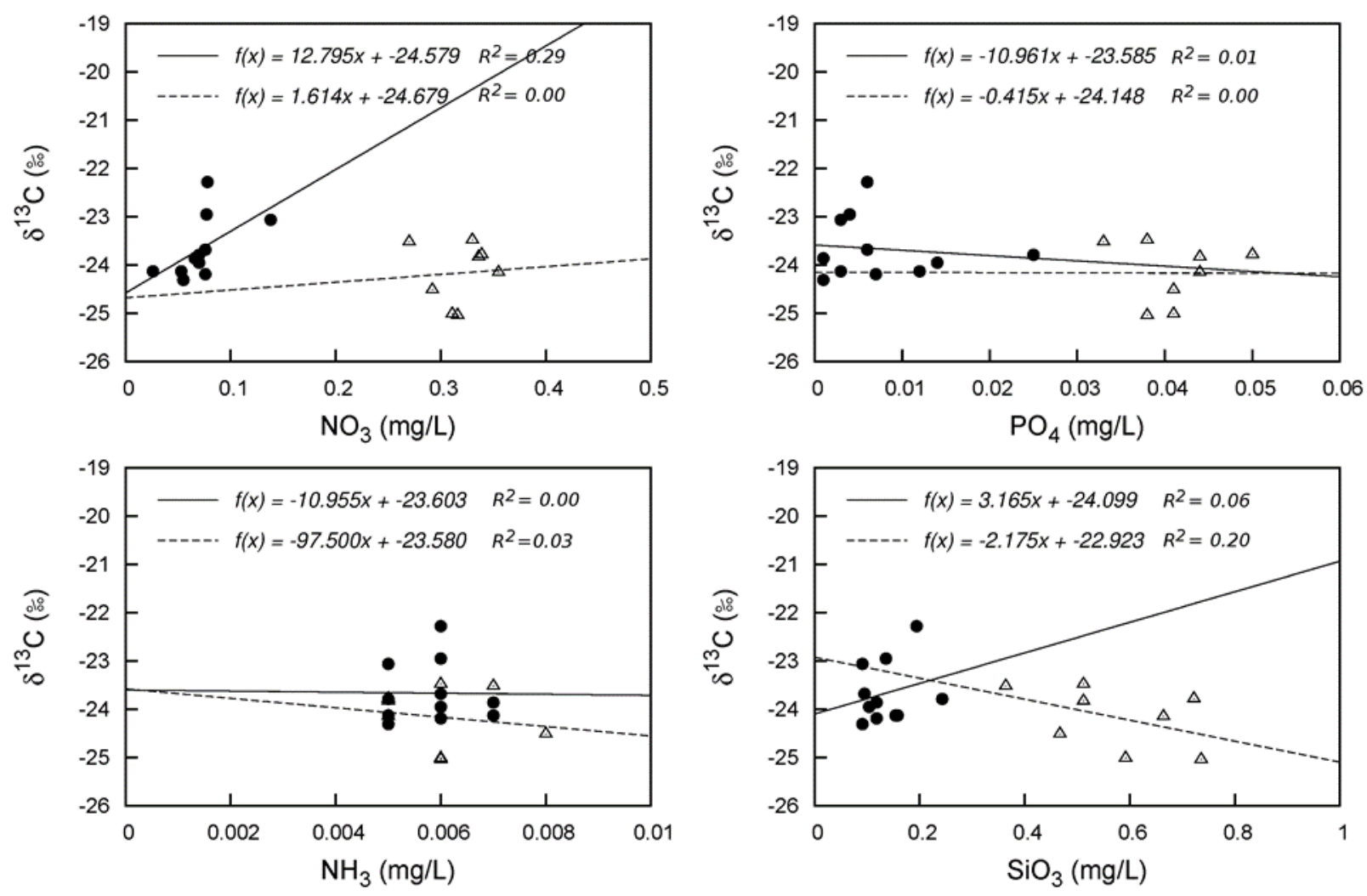

FIGURE 7. Correlation between nutrient parameters and isotopic profile of POM. Filled circles and open triangles are samples from $5 \mathrm{~m}$ and $100 \mathrm{~m}$ depth, respectively.

0.29). There is no significant correlation between nitrate and $\delta^{13} \mathrm{C}$ collected from $100 \mathrm{~m}$. There is a weak correlation shown by other nutrient parameters (silicate, phosphate, ammonium), with $p$-value $>0.05$ (simple linear regression). However, we found that the general trend of our data is similar to Lara et al. (2010), i.e. the phosphate (5 and 100 $\mathrm{m})$ and silicate $(100 \mathrm{~m})$ had a negative correlation with $\delta^{13} \mathrm{C}$. The same trend is shown by the ammonium (Figure 7), although the correlation is weak. Lara et al. (2010) suggested that ammonium, together with POC and sea surface temperature (SST) are independent variables that affected the $\delta^{13} \mathrm{C}$ value, which explained the $83 \% \delta^{13} \mathrm{C}$ variance. On the other hand, nitrate has been suggested to be a variable that affects the $\delta^{15} \mathrm{~N}$ fractionation (Lara et al. (2010) and references therein).

As shown in Figure 2, POM tended to be isotopically lighter with increasing POC and chl- $a$, especially in the surface water at $5 \mathrm{~m}$ depth. However, the opposite trend is shown by water from $100 \mathrm{~m}$ depths; that is the POM's $\delta^{13} \mathrm{C}$ tended to be heavier following the increase of POC. Chl- $a$ and POC are the main proxy of phytoplankton, especially in terms of marine-end member POM (Liu et al. 2007a; Harmelin-Vivien et al. 2008). Lara et al. (2010) suggest that POM tends to be isotopically heavier with increasing phytoplankton biomass proxies such as POC, PON or chl- $a$. Our results show that this suggestion appears only in the depth below $100 \mathrm{~m}$. Although the surface POM is considered to be the marine-end member, it is not freshly produced POM (see sections above). This is another explanation as to why POM collected in the surface layer of Southwestern Sumatran waters does not follow Lara et al. (2010)'s suggestion. Lara et al. (2010) suggest that the large range of $\delta^{13} \mathrm{C}$ is related to phytoplankton metabolism and changes in species composition. This is considered as an adaptation to low nutrient concentrations. Since the nutrient concentra- tions in the Southwestern Sumatran waters are high (see Figure 3 ), the range of $\delta^{13} \mathrm{C}$ should not be large (i.e. -25.10 to $-22.30 \%$ ), which is within our expectation.

\section{CONCLUSION}

The isotopic profile shows that the origin of POM in Southwestern Sumatran waters is as follows. The surface layer (up to $100 \mathrm{~m}$ depth) contains marine-end member POM. Mixed compositions of marine-end member and terrigenous-end member POM are found at the surface of the twilight zone (100 to $300 \mathrm{~m}$ depth). In the twilight zone (300 to $1000 \mathrm{~m}$ depth) the POM is terrigenous end-member and in the deep layer (more than $1000 \mathrm{~m}$ depth) the POM is marine end-member. The surface POM, as shown at $5 \mathrm{~m}$ depth, is not freshly produced, so that POM tends to be isotopically lighter with increasing phytoplankton biomass proxies (i.e. POC or chl-a). The nutrients (i.e. ammonium, nitrate, and phosphate) also show a weak correlation in the isotopic profile of POM. However, the depth-dependent POM's carbon isotope may be caused by the preferential preservation of light carbon isotope, or the preferential remineralization of $\mathrm{N}$ rather than $\mathrm{C}$. A temporal comparison study is still needed, especially during the upwelling that occurs annually in early August. Furthermore, the actual trend of the SSW of the recent years may be different with this study that conducted in 2015. However, our data obtained during this study may be used for validation on modelling biogeochemistry and oceanography.

\section{ACKNOWLEDGMENTS}

This research is part of the Ekspedisi Widya Nusantara (EWIN) research cruise that fully funded by Government of Indonesia through Flagship Program of the Indonesian Insti- 
tute of Sciences (LIPI) fiscal year 2015. The author thanked Mr. Praditya Avianto for providing maps of study site. The author also thanked Dr. Intan S. Nurhati and Mr. Supono for giving the constructive comments. The assistance by our technicians (i.e. Mr. Madisaeni, Mrs. Suci Lastrini, Mr. Sumijo H. Riyono and Mr. Salem Picalouhata) during field sampling and laboratory work, is well acknowledged. Author AJW is the main contributor, following by A and HM as the member contributors.

\section{REFERENCES}

Arístegui J, Duarte CM, Agustí S, Doval M, Álvarez-Salgado XA, Hansell DA. 2002. Dissolved organic carbon support of respiration in the dark ocean. Science. 298(5600):1967-1967. doi:10.1126/science.1076746.

Boyd PW, Sherry ND, Berges JA, Bishop JKB, Calvert SE, Charette MA, Giovannoni SJ, Goldblatt R, Harrison PJ, Moran SB, et al. 1999. Transformations of biogenic particulates from the pelagic to the deep ocean realm. Deep Sea Res, Part II. 46(11):2761-2792. doi:10.1016/S0 967-0645(99)00083-1.

Carter JF, Barwick VJ, editors. 2011. Good practice guide for isotope ratio mass spectrometry. $1^{\text {st }}$ edition. Bristol: FIRMS.

Cavan EL, Trimmer M, Shelley F, Sanders R. 2017. Remineralization of particulate organic carbon in an ocean oxygen minimum zone. Nat Commun. 8(1):1-9. doi: 10.1038/ncomms14847.

Cifuentes LA, Sharp JH, Fogel ML. 1988. Stable carbon and nitrogen isotope biogeochemistry in the Delaware estuary: Carbon and nitrogen isotopes. Limnol Oceanogr. 33(5):1102-1115. doi:10.4319/lo.1988.33.5.1102.

Cochlan W, Hendorn J. 2012. Water quality methods. Tiburon: Romberg Tiburon Center for Environmental Studies, San Fransisco State University.

Gilhooly WP, Macko SA, Flemings PB, Behrman JH, John CM. 2008. Data report: isotope compositions of sedimentary organic carbon and total nitrogen from BrazosTrinity Basin IV (Sites U1319 and U1320) and Ursa Basin (Sites U1322 and U1324), deepwater Gulf of Mexico. Proceedings of the Integrated Ocean Drilling Program. College Station: Integrated Ocean Drilling Program Management International. p. 1-11.

Harmelin-Vivien M, Loizeau V, Mellon C, Beker B, Arlhac D, Bodiguel X, Ferraton F, Hermand R, Philippon X, SalenPicard C. 2008. Comparison of $\mathrm{C}$ and $\mathrm{N}$ stable isotope ratios between surface particulate organic matter and microphytoplankton in the Gulf of Lions (NW Mediterranean). Cont Shelf Res. 28(15):1911-1919. doi: 10.1016/j.csr.2008.03.002.

Hirose K, Saito T, Lee SH, Gastaud J. 2011. Vertical distributions of the strong organic ligand in the twilight zone of southern hemisphere ocean particulate matter. Prog Oceanogr. 89(1):108-119. doi:10.1016/j.pocean.2010.12.0 11.

Hirose K, Tanoue E. 1998. The vertical distribution of the strong ligand in particulate organic matter in the North Pacific. Mar Chem. 59(3):235-252. doi:10.1016/S03044203(97)00095-9.

Hood RR, Naqvi SWA, Wiggert JD, Landry MR, Rixen T, Beckley LE, Goyet C, Cowie GL, Maddison LM. 2011. Sustained Indian Ocean biogeochemistry and ecosystem research (SIBER): A basin wide ecosystem program Science Plan and Implementation Strategy. Technical report. Indian National Center for Ocean Information Services (INCOIS). Hyderabad.
Hwang J, Montluçon DB, Pilskaln CH, Eglinton TI. 2013. Molecular and isotopic insights into particulate organic carbon sources and dynamics in Jordan Basin, Gulf of Maine. Cont Shelf Res. 68:15-22. doi:10.1016/j.csr.2013 .08 .005 .

Jacob U, Mintenbeck K, Brey T, Knust R, Beyer K. 2005. Stable isotope food web studies: a case for standardized sample treatment. Mar Ecol Prog Ser. 287:251-253. doi:10.3354/meps287251.

Kaiser D, Unger D, Qiu G. 2014. Particulate organic matter dynamics in coastal systems of the northern Beibu Gulf. Cont Shelf Res. 82:99-118. doi:10.1016/j.csr.2014.04.00 6.

Lara RJ, Alder V, Franzosi CA, Kattner G. 2010. Characteristics of suspended particulate organic matter in the southwestern Atlantic: influence of temperature, nutrient and phytoplankton features on the stable isotope signature. J Mar Syst. 79(1-2):199-209. doi:10.1016/j.jm arsys.2009.09.002.

Letscher RT, Moore JK, Teng YC, Primeau F. 2015. Variable $\mathrm{C}: \mathrm{N}$ : P stoichiometry of dissolved organic matter cycling in the Community Earth System Model. Biogeosciences. 12(1):209-221. doi:10.5194/bg-12-209-2015.

Liu KK, Kao SJ, Hu HC, Chou WC, Hung GW, Tseng CM. 2007a. Carbon isotopic composition of suspended and sinking particulate organic matter in the northern South China Sea-from production to deposition. Deep Sea Res, Part II. 54(14-15):1504-1527. doi:10.1016/j.dsr2 2007.05.010.

Liu KK, Kao SJ, Wen LS, Chen KL. 2007b. Carbon and nitrogen isotopic compositions of particulate organic matter and biogeochemical processes in the eutrophic Danshuei Estuary in northern Taiwan. Sci Total Environ. 382(1):103-120. doi:10.1016/j.scitotenv.2007.04.01 9.

Martiny AC, Vrugt JA, Lomas MW. 2014. Concentrations and ratios of particulate organic carbon, nitrogen, and phosphorus in the global ocean. Sci Data. 1(1). doi: 10.1038/sdata.2014.48.

Murphy J, Riley JP. 1962. A modified single solution method for the determination of phosphate in natural waters. Anal Chim Acta. 27:31-36. doi:10.1016/S0003-2670 (00)88444-5.

Otero E, Culp R, Noakes JE, Hodson RE. 2000. Allocation of particulate organic carbon from different sources in two contrasting estuaries of southeastern USA. Limnol Oceanogr. 45(8):1753-1763. doi:10.4319/lo.2000.45.8.1 753.

Parsons TR, Maita Y, Lalli CM. 1984. A manual of chemical and biological methods for seawater analysis. Oxford: Pergamon Press.

Post DM. 2002. Using stable isotopes to estimate trophic position: Models, methods, and assumptions. Ecology. 83(3):703-718. doi:10.1890/0012-9658(2002)083[0703: USITET]2.0.CO;2.

Sanders R, Henson SA, Koski M, De La Rocha CL, Painter SC, Poulton AJ, Riley J, Salihoglu B, Visser A, Yool A, Bellerby R, Martin AP. 2014. The biological carbon pump in the North Atlantic. Prog Oceanogr. 129:200-218. doi:10.101 6/j.pocean.2014.05.005.

Sarma VVSS, Krishna MS, Prasad VR, Kumar BSK, Naidu SA, Rao GD, Viswanadham R, Sridevi T, Kumar PP, Reddy NPC. 2014. Distribution and sources of particulate organic matter in the Indian monsoonal estuaries during monsoon. Journal of Geophysical Research: Biogeosciences. 119(11):2095-2111. doi:10.1002/2014JG002721. 
Schott FA, Xie SP, McCreary JP. 2009. Indian Ocean circulation and climate variability. Rev Geophys. 47(1). doi:10.1029/2007RG000245.

Strickland JD, Parsons TR. 1972. A practical handbook of seawater analysis. $2^{\text {nd }}$ edition. Bulletin 167. Ottawa: Fisheries Research Board of Canada.

Susanto RD, Gordon AL, Zheng Q. 2001. Upwelling along the coasts of Java and Sumatra and its relation to ENSO. Geophys Res Lett. 28(8):1599-1602. doi:10.1029/2000 GL011844.

Turner JT. 2015. Zooplankton fecal pellets, marine snow, phytodetritus and the ocean's biological pump. Prog Oceanogr. 130:205-248. doi:10.1016/j.pocean.2014.08 .005 .

Wahyudi AJ, Iskandar MR, Rachman A, Meirinawati $\mathrm{H}$, Darmayati Y. 2015. Exploring Eastern Indian Ocean through E-WIN: a contribution to IIOE-2. The Indian
Ocean Bubble 2. (3):11-12.

Wahyudi AJ, Wada S, Aoki M, Hama T. 2013. Stable isotope signature and pigment biomarker evidence of the diet sources of Gaetice depressus (Crustacea: Eubrachyura: Varunidae) in a boulder shore ecosystem. Plankton Benthos Res. 8(2):55-67. doi:10.3800/pbr.8.55.

Wassmann P. 1997. Retention versus export food chains: processes controlling sinking loss from marine pelagic systems. Hydrobiologia. 363(1):29-57. doi:10.1023/A: 1003113403096.

Yu W, Hood R, D’Adamo N, McPhaden M, Adi R, Tisiana R, Kuswardani D, Feng M, Ivey G, Lee T, et al. 2016. Eastern Indian Ocean Upwelling Research Initiative (EIOURI) Science Plan: The EIOURI Science Plan. Technical report. ESSO - Indian National Centre for Ocean Information Services. Hyderabad. 